the Dakar modified yellow fever virus associated with smallpox vaccine (see also section on Immunization in the First Six Months).

\section{Summary and Conclusions}

The formidable list of inoculations now considered necessary for immunization is reduced by combined prophylactics. Procedures for different age groups from birth onwards are discussed.

In the early months of life maternal antibodies transferred via the placenta may be present in sufficient concentration to interfere with active immunization.

Vaccination against smallpox should probably be done in thriving infants about the third or fourth month, preferably three weeks before other immunization is begun. Although diphtheria-pertussis or diphtheriatetanus-pertussis prophylactics are not yet officially sponsored by the Ministry of Health, these preparations are being used increasingly: three injections at fourweekly intervals are given subcutaneously. B.C.G. vaccination in infancy has also been advocated (for contacts), but should not be given less than three weeks after smallpox vaccination. It is not known whether repeated, doses of B.C.G. vaccine would interfere with the responses to other antigens.

Allergic children can usually be immunized in early life without untoward effects, although it is prudent to begin with small detector doses.

The official attitude to immunizing procedures in the U.S.A. and Great Britain is discussed. Proposals which are immunologically desirable are not always administratively practicable. It is suggested as a working compromise that there should be a general "call-up" of children at 1 year of age: those who have already had their primary combined immunization could be given a boosting dose, while the others would receive three doses.

The number of boosting injections necessary for lifelong immunity largely depends on whether the primary course is "adequate" to confer a high degree of protection to all but exceptional individuals for at least one year.

Combined diphtheria-tetanus toxoid used as a boosting dose for schoolchildren may produce considerable diphtheria antitoxin but very little tetanus antitoxin if the children have already been immunized against diphtheria only. Methods are suggested for obviating this type of interference.

Adult immunization with combined preparations such as T.A.B.T.D. sometimes presents a difficult problem on account of wide variations in the immunity state of individuals. Alternative procedures are discussed.

Before a procedure is taken into general use, research is always indicated on the extent and duration of antibody responses. This information is obtained by examining representative blood samples.

Owing to the variety of immunization procedures now in use and the need for essential information being readily available in an emergency, a record card of inoculations should be kept by parents. This record is not intended to replace the more detailed information retained by doctors or public health authorities. Haphazard and unrecorded immunizations are to be deprecated.

I wish to thank my colleagues, Colonel H. W. Mulligan, Mr. A. T. Glenny, F.R.S., and Miss M. Barr, for much helpful discussion and constructive criticism. I am also indebted to Dr. W. H. Bradley, Ministry of Health, for a number of valuable suggestions.

\section{REPERENCES}

American Public Health Association (1955). Control of Communicable Discases in Man.

Barr, M. (1953). British Medical Journal, 2, 1099.

Glenny, A. T., and Randall, K. J. (1949). Lancet, 2, 324.

and (1950). Ibid., $1,6$.

and Llewellyn-Jones, M. (1953a). Brit. J. exp. Path., 34, 12

- 1 (1953b). Ibid., 34, 233.

Bousfield, G., and Holt, L. B. (1954). Med. Offr, 92, 289.

de Assis, A. (1953). Hoja tisiol., 13, 325.

Edsall, G., Altman, J. S., and Gaspar, A. J. (1954). Amer. J. publ. Hlth, 44,1537

Heaf, F. R. G. (1955). Lancet, 1, 315

London County Council (1953). Report of the County Medical Officer and School Medical Officer.

Ministry of Health (1952). Memorandum on Vaccination against Smallpox. H.M.S.O., London.

Parish, H. J.' (1951). British Medical Journal, 1, 1164

Barr, M., Ungar, J., and Butler, N. R. (1954). Proc, roy. Soc. Med. 47, 351 .

Peach, A. M., and Rhodes, A. J. (1954). Amer. J. Publ. Hlth, 44, 1185.

Sayé, L. (1953). Acta phtisiol. (Paris), 2, 10.

\section{IMMUNIZATION OF BABIES WITH DIPHTHERIA-TETANUS-PERTUSSIS PROPHYLACTIC}

BY

MOLLIE BARR, M.Sc., A.R.I.C.

A. T. GLENNY, B.Sc., F.R.S.

AND

N. R. BUTLER, M.D., M.R.C.P., D.C.H.

From the Wellcome Research Laboratories (Biological Division) and the L.C.C. Infant Welfare Clinic of University College Hospital Medical School

Although immunization of babies with combined diphtheria-tetanus-pertussis prophylactics has been practised in the U.S.A. and Canada for some years, it is only recently that such preparations have been used in this country.

This paper gives the results of immunization trials in which two triple prophylactics were used. Preliminary results were shown by two of us at the Royal Society of Medicine (January, 1954), and by one of us at the British Paediatric Association meeting (April, 1954). Both preparations contained, per ml., $60 \mathrm{Lf}$ of purified diphtheria toxoid, $12 \mathrm{Lf}$ of purified tetanus toxoid, and $4 \times 10^{10}$ $H$. pertussis : in one, the toxoids were adsorbed on to aluminium hydroxide, and in the other no mineral carrier was present. These prophylactics are referred to respectively as the "adsorbed" and the "fluid" preparation. The dose injected into babies was in all cases $0.5 \mathrm{ml}$. The objects of this work were to determine whether satisfactory immunity could be established in very young babies given the first of a course of three injections of adsorbed prophylactic at the age of a week, and to determine the optimum age at which to begin immunization with the fluid preparation. The question of age at the time of the first dose is of special importance when combined prophylactics are used. Many babies in this country are born with circulating passive diphtheria antitoxin acquired by maternal transmission. The titre of this antitoxin is high enough, in some babies, to neutralize and interfere with the action of a dose of diphtheria prophylactic if this is given at an early age.

Active immunization against tetanus, however, is still very rare, and babies seldom therefore acquire tetanus antitoxin from their mothers. In order to obtain satisfactory. immunity to both diphtheria and tetanus, in the great majority of babies, immunization should be started 
at a time when the maternally conferred diphtheria antitoxin has fallen below the level at which it will interfere with the action of the diphtheria toxoid in the prophylactic. It has been shown that, in normal guineapigs immunized with two doses of combined diphtheriatetanus prophylactics, the immunity produced may be dependent on the relative proportions of the component antigens : an excess of tetanus toxoid lowered the diphtheria response (Barr and Llewellyn-Jones, 1953 ; Barr, 1954). A similar result might be expected to occur in babies with high passively acquired titres of diphtheria antitoxin. Partial neutralization of the diphtheria toxoid by this circulating antitoxin would reduce its effective potency, and the effect would be that produced by the injection of an unbalanced mixture containing excess tetanus toxoid. The tetanus responses would remain unaltered.

\section{Technique of Immunization}

The scheme of immunization used in this work is shown in Table I. Samples of blood were taken from the umbilical cord in order to determine the titre of maternally conferred diphtheria antitoxin. Blood samples were taken

TABLE I.-Scheme of Immunization of Babies with Three Doses of Triple Prophylactic

\begin{tabular}{|c|c|c|c|c|c|c|c|}
\hline Group & Prophylactic & $\begin{array}{l}\text { Age when Injected } \\
\text { (Weeks) }\end{array}$ & \multicolumn{5}{|c|}{$\begin{array}{c}\text { Date of } \\
\text { First Sampling }\end{array}$} \\
\hline $\begin{array}{l}\mathbf{S} \\
\mathbf{T} \\
\mathbf{V} \\
\mathbf{Y}\end{array}$ & $\begin{array}{l}\text { Adsorbed } \\
\text { Fluid } \\
\text { ", } \\
\text { " }\end{array}$ & $\begin{array}{r}1,6,14 \\
6,12,18 \\
12,16,20 \\
16,20,24\end{array}$ & $\begin{array}{l}12 \text { we } \\
8 \\
8 \\
8\end{array}$ & $\begin{array}{l}\text { eeks } \\
\text { ", }\end{array}$ & $\begin{array}{c}\text { after } \\
\text { ", } \\
\text {," }\end{array}$ & $\begin{array}{c}3 \text { rd } \\
\text { ": } \\
\text { ", }\end{array}$ & $\begin{array}{l}\text { dose } \\
\text { ", } \\
\text { ", }\end{array}$ \\
\hline
\end{tabular}

A reinforcing dose of the fluid preparation was given to all groups at the age of 52 weeks.

from the babies at the age of approximately 6 months, to test the early responses to the course of immunization. Additional samples were taken later to provide an estimate of the duration of immunity and to test the response to a reinforcing dose of prophylactic. Titrations for diphtheria antitoxin were made by the guinea-pig intracutaneous method described by Glenny and Llewellyn-Jones (1931) and for tetanus antitoxin by the mouse method (Glenny and Stevens, 1938). All blood samples were taken by internal jugular venepuncture; in the present series over 1,000 such procedures were carried out without incident. Injections were made subcutaneously.

In practice there were considerable deviations from the exact scheme set out in Table I. The individual babies were placed in groups $T, V$, or $Y$ according to the nearest approximation of age, at the time of the first injection, to the ages set out in Table I.

The great majority of the babies were born in the University College Hospital Obstetric Department during 1953 and 1954. The immunization scheme and the object of immunization with the triple prophylactic were explained personally and by pamphlet to the mothers early in the puerperium, and their co-operation was obtained. It was impressed upon the mothers that in the future they should give the information that their children had been actively immunized against tetanus if they had any accident and treatment with tetanus antitoxin was under consideration.

\section{Results}

Table II gives the antitoxin titres of blood samples taken after immunization of babies from all groups at the ages of approximately 6 months and 12 months and, in addition, three months after a reinforcing (4th) dose of combined prophylactic. For this reinforcing dose the fluid preparation was used for all four groups. More than half the babies in each group had titres of circulating antitoxin of between 0.2 and 1 unit per ml. at 6 months. It is, however, evident that the responses of group $\mathrm{T}$ were lèss satisfactory than those of the other groups. This is evident
TABLE II.-Diphtheria Antitoxin Titres of Babies After Immunization with Triple Prophylactic

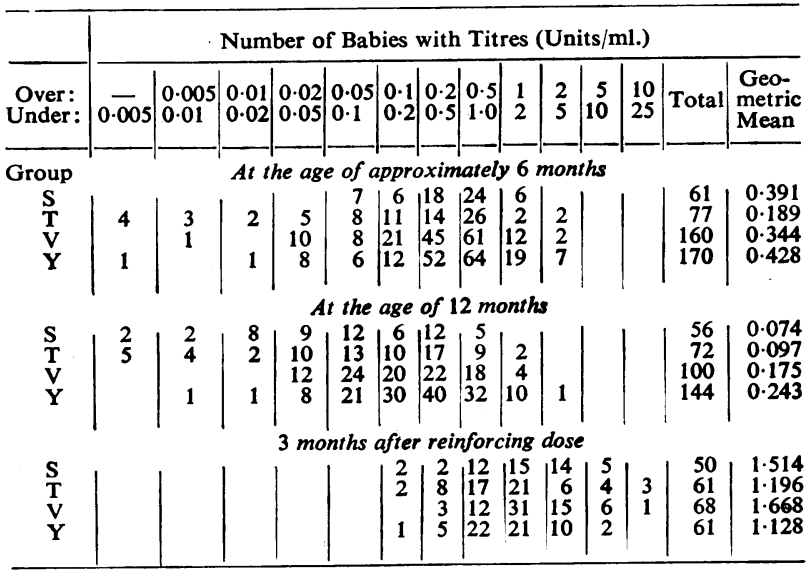

from the geometric mean titre and, which is more important, from the large scatter: 4 of the 77 babies would be expected to be Schick-positive, and there is a marked downward tail from the peak of the distribution of titres. At the age of a year the responses of group $T$ were again inferior to those of groups $\mathrm{V}$ and $\mathrm{Y}$ which received the same prophylactic.

It is, however, interesting to note that a much greater fall in titre occurred in babies of group S, between 6 and 12 months; these babies had received three doses of the adsorbed prophylactic which had caused rather severe reactions. After the reinforcing dose, however, there was little difference in the immunity state of the babies in any of the groups. This reinforcing dose must be regarded as an essential part of any scheme of immunization. The reduction in the incidence of the disease suggests that $C$. diphtheriae has probably become rare in many parts of the country. The consequent rarity of subclinical infection will greatly reduce the maintenance of immunity, and higher titres must be aimed at in artificial immunization. The Schick test, which has contributed so much to success in the past, is now of far less value in any work upon schemes of immunization.

Table III gives the tetanus antitoxin titres of the same babies. There was no difference between the group responses at 6 months, but there is again a suggestion of a greater

Table III.-Tetanus Antitoxin Titres of Immunized Babies

\begin{tabular}{|c|c|c|c|c|c|c|c|c|c|c|c|c|}
\hline \multirow[b]{2}{*}{$\begin{array}{c}\text { Over: } \\
\text { Under: }\end{array}$} & \multicolumn{12}{|c|}{ Number of Babies with Titres (Units /ml.) } \\
\hline & $\begin{array}{l}0.1 \\
0.25\end{array}$ & $\begin{array}{l}0.25 \\
0.5\end{array}$ & $\begin{array}{l}0.5 \\
1.0\end{array}$ & $\begin{array}{l}1.0 \\
2.5\end{array}$ & $\begin{array}{l}2.5 \\
5.0\end{array}$ & $\begin{array}{r}5 \\
10\end{array}$ & $\begin{array}{l}10 \\
25\end{array}$ & $\begin{array}{l}25 \\
50\end{array}$ & $\begin{array}{r}50 \\
100\end{array}$ & $\begin{array}{l}100 \\
250\end{array}$ & Total & $\begin{array}{l}\text { Geo- } \\
\text { metric } \\
\text { Mean }\end{array}$ \\
\hline $\begin{array}{c}\text { Group } \\
\mathbf{S} \\
\mathbf{T} \\
\mathbf{V} \\
\mathbf{Y}\end{array}$ & & $\begin{array}{l}2 \\
1\end{array}$ & $\begin{array}{l}A \\
3 \\
2 \\
6 \\
5\end{array}$ & $\begin{array}{l}\text { the } \\
16 \\
9 \\
25 \\
37\end{array}$ & $\begin{array}{c}\text { age o } \\
20 \\
37 \\
55 \\
59\end{array}$ & $\begin{array}{l}a p p \\
18 \\
25 \\
66 \\
63\end{array}$ & \begin{tabular}{r|}
$r o x i m$ \\
2 \\
4 \\
6 \\
5
\end{tabular} & ately & $6 \mathrm{mo}$ & ths & $\begin{array}{r}61 \\
77 \\
160 \\
169\end{array}$ & $\begin{array}{l}3 \cdot 16 \\
4 \cdot 18 \\
4 \cdot 13 \\
3 \cdot 83\end{array}$ \\
\hline $\begin{array}{l}\mathbf{S} \\
\mathbf{T} \\
\mathbf{V} \\
\mathbf{Y}\end{array}$ & $\begin{array}{l}7 \\
2 \\
1\end{array}$ & $\begin{array}{l}8 \\
1 \\
4 \\
5\end{array}$ & $\begin{array}{l}10 \\
10 \\
13 \\
20\end{array}$ & $\begin{array}{l}18 \\
33 \\
49 \\
58\end{array}$ & $\begin{array}{l}\text { At th } \\
\begin{array}{|l}11 \\
18 \\
21 \\
40\end{array}\end{array}$ & $\begin{array}{r}\text { e age } \\
2 \\
8 \\
8 \\
11\end{array}$ & of 12 & mon & ths & 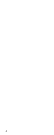 & $\begin{array}{r}56 \\
72 \\
96 \\
135\end{array}$ & $\begin{array}{l}1.02 \\
1.88 \\
1.76 \\
1.94\end{array}$ \\
\hline $\begin{array}{l}\mathbf{S} \\
\mathbf{T} \\
\mathbf{V} \\
\mathbf{Y}\end{array}$ & & I & 1 & $\begin{array}{l}3 \\
2\end{array}$ & $\begin{array}{l}\text { nonth } \\
\begin{array}{|r}7 \\
9 \\
13 \\
17\end{array}\end{array}$ & $\begin{array}{l}\text { afte } \\
28 \\
22 \\
26 \\
29\end{array}$ & $\begin{array}{l}r \text { rein } \\
\mid \begin{array}{l}11 \\
26 \\
23 \\
9\end{array}\end{array}$ & $\begin{array}{c}f o r c i \\
2 \\
3 \\
2 \\
4\end{array}$ & $\begin{array}{c}g \text { dos } \\
1 \\
1 \\
1\end{array}$ & 1 & $\begin{array}{l}50 \\
61 \\
69 \\
62\end{array}$ & $\mid \begin{array}{c}8 \cdot 17 \\
10 \cdot 1 \\
8 \cdot 62 \\
6 \cdot 69\end{array}$ \\
\hline
\end{tabular}

fall in titre in group $S$ between the 6- and 12-month samplings. This poorer duration of immunity may be related either to the type of prophylactic used (adsorbed), to the earlier start of immunization, to the spacing of doses, or, most probably, to the severe reactions produced, which may have reduced the capacity of the babies for "continued production" of antitoxin. 
The antitoxin titres shown in Tables II and III were those of all babies bled, no account having been taken of the circulating passive diphtheria antitoxin present in some babies from maternal transmission. They therefore represent random samples from this particular population. Table IV shows the geometric mean diphtheria antitoxin

TABLE IV.-Geometric Means of the Diphtheria Antitoxin Titres of Immunized Babies

\begin{tabular}{|c|c|c|c|c|c|c|c|c|c|c|}
\hline & \multicolumn{5}{|c|}{ Geometric Means (Units $/ \mathrm{ml}$.) } & \multicolumn{5}{|c|}{ Number of Babies } \\
\hline & \multicolumn{10}{|c|}{ Cord Blood Titre } \\
\hline & $0 . \overline{001}$ & $\begin{array}{l}0.001 \\
0.1\end{array}$ & $\begin{array}{l}0 \cdot 1 \\
1 \cdot 0\end{array}$ & $\begin{array}{r}1 \\
10\end{array}$ & $\left|\begin{array}{c}\text { Un- } \\
\text { known }\end{array}\right|$ & $0 . \overline{001}$ & $\begin{array}{l}0.001 \\
0.1\end{array}$ & $\left|\begin{array}{l}0.1 \\
1.0\end{array}\right|$ & $\begin{array}{r}1 \\
10\end{array}$ & $\begin{array}{c}\text { Un- } \\
\text { known }\end{array}$ \\
\hline $\begin{array}{c}\text { Group } \\
\mathbf{S} \\
\mathbf{T} \\
\mathbf{V} \\
\mathbf{Y}\end{array}$ & \begin{tabular}{|l|l}
0.638 \\
0.475 \\
0.428 \\
0.469
\end{tabular} & $\mid \begin{array}{l}0.461 \\
0.292 \\
0.550 \\
0.587\end{array}$ & $\begin{array}{l}\text { At the } \\
\begin{array}{|l|}0.319 \\
0.033 \\
0.170 \\
0.281\end{array}\end{array}$ & $\begin{array}{l}\text { age of } \\
0.083 \\
(0.122) \\
0.020 \\
0.316\end{array}$ & $\begin{array}{l}\text { approxi } \\
(0 \cdot 071) \\
(0.069) \\
0.308 \\
0.387\end{array}$ & $\begin{array}{l}\text { mately } \\
\begin{array}{|c|}20 \\
24 \\
62 \\
56\end{array}\end{array}$ & $\begin{array}{l}6 \text { month } \\
\begin{array}{|c}21 \\
28 \\
43 \\
48\end{array}\end{array}$ & $\begin{array}{l}h s \\
13 \\
17 \\
27 \\
39\end{array}$ & $\begin{array}{l}6 \\
4 \\
5 \\
7\end{array}$ & $\begin{array}{r}1 \\
4 \\
23 \\
20\end{array}$ \\
\hline $\begin{array}{l}\mathbf{S} \\
\mathrm{T} \\
\mathrm{V} \\
\mathbf{Y}\end{array}$ & $\mid \begin{array}{l}0.139 \\
0.290 \\
0.243 \\
0.275\end{array}$ & $\mid \begin{array}{l}0.111 \\
0.104 \\
0.218 \\
0.356\end{array}$ & $\mid \begin{array}{l}0.053 \\
0.020 \\
0.093 \\
0.147\end{array}$ & $\begin{array}{l}\text { At the } \\
\left|\begin{array}{c}0.0098 \\
(0.068) \\
(0.071) \\
0.118\end{array}\right|\end{array}$ & $\begin{array}{l}\text { age of } 1 \\
(0.007) \\
(0.032) \\
0.127 \\
0226\end{array}$ & $\begin{array}{l}2 \text { mont } \\
17 \\
24 \\
40 \\
52\end{array}$ & $\begin{array}{l}\text { hs } \\
\begin{array}{|l}21 \\
27 \\
24 \\
38\end{array}\end{array}$ & $\begin{array}{l}11 \\
15 \\
18 \\
29\end{array}$ & $\begin{array}{l}6 \\
3 \\
2 \\
7\end{array}$ & $\begin{array}{r}1 \\
3 \\
16 \\
18\end{array}$ \\
\hline $\begin{array}{l}\mathbf{S} \\
\mathbf{T} \\
\mathbf{V} \\
\mathbf{Y}\end{array}$ & $\begin{array}{l}1.87 \\
2.60 \\
1.73 \\
1.07\end{array}$ & $\begin{array}{l}1.90 \\
0.94 \\
2.32 \\
1.58\end{array}$ & 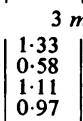 & $\begin{array}{l}\text { months a } \\
\mid \begin{array}{l}(0.38) \\
(1.17) \\
(0.67) \\
(0.68)\end{array}\end{array}$ & $\begin{array}{l}\text { after rein } \\
\left|\begin{array}{l}(0.32) \\
(1.12) \\
(1.325) \\
0.79\end{array}\right|\end{array}$ & $\begin{array}{c}\text { uforcing } \\
16 \\
20 \\
32 \\
15\end{array}$ & $\begin{array}{r}\text { dose } \\
\mid \begin{array}{r}21 \\
21 \\
15 \\
20\end{array}\end{array}$ & $\begin{array}{r}8 \\
14 \\
11 \\
18\end{array}$ & $\begin{array}{l}4 \\
3 \\
2 \\
3\end{array}$ & $\begin{array}{l}1 \\
3 \\
9 \\
5\end{array}$ \\
\hline
\end{tabular}

titres of the same babies, subdivided according to cord blood values. The numbers in some groups are very small, and the mean values of groups of less than five babies have been enclosed in parentheses. It is probable that almost all the diphtheria antitoxin titres shown in Tables II and IV represent actively produced antitoxin. In uninjected babies the residual passive antitoxin present at any age can be calculated by means of a formula given by Barr, Glenny, and Randall (1949). This shows that passively acquired homologous antitoxin in babies has a half-life of about 32 days. The injection of $30 \mathrm{Lf}$ of diphtheria toxoid must have further reduced the quantity of free antitoxin, particularly in babies in series $\mathbf{V}$ and $\mathbf{Y}$, who were injected when the passive antitoxin was already much reduced.

If the formula of Barr et al. is correct it must be rare for any infant 12 months old to have sufficient passively acquired antitoxin to be Schick-negative. Among the first 4,000 samples of cord blood collected from London hospitals, almost all from U.C.H., only two have been found with a titre sufficiently high that $0.005 \mathrm{unit} / \mathrm{ml}$. would remain at the age of 12 months. Bousfield and Holt (1954) have summarized the results of Schick tests done by Dr. Guy Bousfield on $\mathbf{8 , 8 4 6}$ children in and immediately around London. Their chart shows that $2 \%$ of 724 children 12 or 13 months old, and about $1.5 \%$ of 263 when 14 or 15 months old, were Schick-negative. It is possible that these children had become actively immunized by subclinical infection.

The titres of babies in group $\mathrm{S}$, who received the adsorbed prophylactic, suggest that there was little or no interference with the early response to the diphtheria toxoid, except in those whose cord blood titres had been 1 unit per ml. or higher. Similarly, there was little difference in the 32week mean titres of babies in group $Y$. In group $V$ interference with the response occurred in some babies with cord blood titres between 0.1 and 1 unit per ml., and in group $T$ the geometric mean titre decreased steadily with increasing cord blood value. The fall in antitoxin titre between the first and second occasions of sampling was uniformly great throughout group $S$, and appears to have been least in group Y.

The analysis of the 6- and 12-month titres shows that very satisfactory immunity was established in babies injected with the fluid preparation at the ages of 16,20 , and 24 weeks (group Y), and that the great majority were satisfactorily immunized when the first dose was given at 12 weeks (group V). All of the 244 babies in series V and Y tested at the age of 12 months had enough antitoxin to render them Schick-negative. The results suggest that diphtheria immunity would be inadequate in too great a proportion when the course of injections was started at 6 weeks (group T). It would also appear that the adsorbed prophylactic did not establish sufficient "continued production" when administered at 1,6 , and 14 weeks. It is interesting to note that the geometric mean titres of group $T$, after the reinforcing dose, showed a continuation of the effects of interference by maternally conferred antitoxin, noted in the 6- and 12-month titres.

Table $\mathrm{V}$ gives the geometric mean tetanus antitoxin titres of these babies subdivided according to the diphtheria antitoxin values of the cord blood samples. It is clear that the

TABLE V.-Geometric Means of the Tetanus Antitoxin Titres of Immunized Babies

\begin{tabular}{|c|c|c|c|c|c|c|c|c|c|c|}
\hline \multicolumn{6}{|c|}{ Geometric Means (Units/ml.) } & \multicolumn{5}{|c|}{ Number of Babies } \\
\hline \multicolumn{11}{|c|}{ Cord Blood Titres of Diphtheria Antitoxin } \\
\hline $\begin{array}{l}\text { Over: } \\
\text { Under }\end{array}$ & $0 . \overline{001}$ & $\mid \begin{array}{l}0.001 \\
0.1\end{array}$ & $\begin{array}{l}0.1 \\
1.0\end{array}$ & $\begin{array}{r}1 \\
10 \\
\end{array}$ & $\mid \begin{array}{c}\text { Un- } \\
\text { known }\end{array}$ & $0 . \overline{001}$ & $\begin{array}{l}0.001 \\
0.1\end{array}$ & \begin{tabular}{|l|}
0.1 \\
1.0
\end{tabular} & $\begin{array}{r}1 \\
10 \\
\end{array}$ & $\begin{array}{c}\text { Un- } \\
\text { known }\end{array}$ \\
\hline $\begin{array}{c}\text { Group } \\
\mathbf{S} \\
\mathbf{T} \\
\mathbf{V} \\
\mathbf{Y}\end{array}$ & $\begin{array}{l}2.91 \\
4.39 \\
4.02 \\
3.69\end{array}$ & $\begin{array}{l}4.08 \\
4.40 \\
4.58 \\
4.40\end{array}$ & $\begin{array}{r}\text { At the } \\
2.55 \\
3.42 \\
4.24 \\
3.54\end{array}$ & $\begin{array}{r}\text { age of } \\
\begin{array}{|l}3.03 \\
(5.00) \\
3.38 \\
4.24\end{array}\end{array}$ & 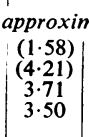 & $\begin{array}{c}\text { nately } \\
20 \\
24 \\
62 \\
57\end{array}$ & $\begin{array}{l}\text { months } \\
21 \\
28 \\
43 \\
47\end{array}$ & \begin{tabular}{|l|}
13 \\
17 \\
28 \\
40
\end{tabular} & $\begin{array}{l}6 \\
4 \\
5 \\
7\end{array}$ & $\begin{array}{r}1 \\
4 \\
22 \\
18\end{array}$ \\
\hline $\begin{array}{l}\mathbf{S} \\
\mathbf{T} \\
\mathbf{V} \\
\mathbf{Y}\end{array}$ & $\begin{array}{l}1.17 \\
2.06 \\
1.82 \\
1.75\end{array}$ & $\begin{array}{l}1 \cdot 36 \\
2.15 \\
1.76 \\
2 \cdot 24\end{array}$ & $\begin{array}{l}0.85 \\
1.36 \\
1.79 \\
1.77\end{array}$ & $\begin{array}{l}\text { At the } \\
0.50 \\
(2.07) \\
(1.58) \\
2.77\end{array}$ & $\begin{array}{l}\text { age of } 12 \\
\left|\begin{array}{c}(0 \cdot 16) \\
(1.21) \\
1.59 \\
1.84\end{array}\right|\end{array}$ & $\begin{array}{c}2 \text { month } \\
17 \\
24 \\
40 \\
45\end{array}$ & $\begin{array}{l}21 \\
27 \\
21 \\
38\end{array}$ & $\begin{array}{l}11 \\
15 \\
18 \\
29\end{array}$ & $\begin{array}{l}6 \\
3 \\
1 \\
7\end{array}$ & $\begin{array}{r}1 \\
3 \\
16 \\
16\end{array}$ \\
\hline $\begin{array}{l}\mathbf{S} \\
\mathbf{T} \\
\mathrm{V} \\
\mathrm{Y}\end{array}$ & $\begin{array}{r}6.92 \\
10 \cdot 0 \\
8.04 \\
6.30\end{array}$ & $\mid \begin{array}{c}9 \cdot 66 \\
10 \cdot 2 \\
11 \cdot 0 \\
6 \cdot 71\end{array}$ & $\begin{array}{r}3 n \\
7.17 \\
8.19 \\
8.35 \\
6.98\end{array}$ & $\begin{array}{l}\text { nonths a } \\
\mid\left(\begin{array}{l}(8.89) \\
(15.8) \\
(3.34) \\
(15.8)\end{array}\right.\end{array}$ & $\begin{array}{l}\text { after rein } \\
\left|\begin{array}{c}(7 \cdot 07) \\
(15 \cdot 8) \\
9 \cdot 36 \\
4 \cdot 06\end{array}\right|\end{array}$ & $\begin{array}{c}\text { forcing } \\
16 \\
19 \\
32 \\
15\end{array}$ & $\begin{array}{r}\text { ose } \\
21 \\
22 \\
15 \\
20\end{array}$ & $\begin{array}{r}8 \\
14 \\
11 \\
19\end{array}$ & $\begin{array}{l}4 \\
3 \\
2 \\
3\end{array}$ & $\begin{array}{l}1 \\
3 \\
9 \\
5\end{array}$ \\
\hline
\end{tabular}

presence of varying amounts of passively acquired diphtheria antitoxin had no effect on the response to immunization with the tetanus toxoid in the combined prophylactic. There was little difference between the tetanus antitoxin titres, shown in Table III, of groups T, V, and Y, which received the first dose at different ages; and Table $V$ shows no significant progressive increase or decrease in geometric titre with increasing diphtheria antitoxin titre of the cord blood. It would thus appear that satisfactory immunity to tetanus toxoid can be produced in this prophylactic when immunization is started as early as the age of 6 weeks. It is interesting to note also that the reduction in efficiency of the diphtheria toxoid, resulting from neutralization by high titres of circulating passive antitoxin in some babies, did not have the effect of increasing their response to the tetanus toxoid. It is possible, however, that, in addition to the reduction in the effective dose of diphtheria toxoid, the responses of such babies to this component may have been further reduced by the resulting disturbance in the balance of the proportions of the two toxoids.

\section{Correlation Between Responses}

Barr and Glenny (1950) showed that in large groups of normal horses immunized with two injections of different antigens there was a rough correlation between the responses to these antigens. Comparisons were made between responses to diphtheria and tetanus alum-precipitated toxoids, and between responses to tetanus and $\mathrm{Cl}$. oedematiens alumprecipitated toxoids and $\mathrm{Cl}$. septicum toxin.

Analysis of the present results in babies shows (Table VI) a similar rough correlation between the diphtheria and tetanus responses in all groups. In every group on each of the three occasions of bleeding the tetanus antitoxin titres of babies with the lowest diphtheria values were, on the average, lower than those of babies with the highest diphtheria values. In most instances it was possible to arrange the diphtheria results into three or four groups of ascending titres ; almost invariably the geometric means of the corresponding tetanus titres increased in the same order, although not to the same extent. The immunizability, to use a term 
TABle VI.-Correlation Between Diphtheria and Tetanus Antitoxin Titres in Babies with Cord Blood Titres of 0.04 unit $/ \mathrm{ml}$. or Less of Diphtheria Antitoxin

\begin{tabular}{|c|c|c|c|c|}
\hline \multirow{2}{*}{ Group } & \multirow{2}{*}{$\begin{array}{l}\text { No. of } \\
\text { Babies }\end{array}$} & \multicolumn{2}{|c|}{ Diphtheria Titres } & \multirow{2}{*}{$\begin{array}{l}\text { Tetanus } \\
\text { Titres: } \\
\text { Geometric } \\
\text { Mean }\end{array}$} \\
\hline & & Range & $\begin{array}{l}\text { Geometric } \\
\text { Mean }\end{array}$ & \\
\hline \multicolumn{5}{|c|}{ Babies bled at the age of approximately 6 months } \\
\hline $\mathbf{S}$ & $\begin{array}{l}15 \\
26\end{array}$ & $\begin{array}{l}0.05-0.2 \\
0.5,1 \cdot 0\end{array}$ & $\begin{array}{l}0.25 \\
0.83\end{array}$ & $\begin{array}{l}\mathbf{2 . 3 3} \\
\mathbf{3} \cdot 96\end{array}$ \\
\hline $\mathbf{T}$ & $\begin{array}{r}7 \\
17 \\
28\end{array}$ & $\begin{array}{c}0.005-0.05 \\
0 \cdot 1,0 \cdot 2 \\
0.5-2 \cdot 0\end{array}$ & $\begin{array}{l}0.056 \\
0.24 \\
0.83\end{array}$ & $\begin{array}{l}2.51 \\
3.76 \\
5.70\end{array}$ \\
\hline $\mathbf{V}$ & $\begin{array}{l}17 \\
27 \\
50 \\
11\end{array}$ & $\begin{array}{c}0 \cdot 05-0 \cdot 1 \\
0 \cdot 2 \\
0 \cdot 5 \\
1 \cdot 0.2 \cdot 0\end{array}$ & $\begin{array}{l}0.12 \\
0.32 \\
0.71 \\
1.42\end{array}$ & $\begin{array}{l}2.88 \\
3.02 \\
4.75 \\
9.46\end{array}$ \\
\hline $\mathbf{Y}$ & $\begin{array}{l}11 \\
34 \\
43 \\
18\end{array}$ & $\begin{array}{c}0.02-0 \cdot 1 \\
0.2 \\
0 \cdot 5 \\
1 \cdot 0,2 \cdot 0\end{array}$ & $\begin{array}{l}0.10 \\
0.32 \\
0.71 \\
1.77\end{array}$ & $\begin{array}{l}2 \cdot 08 \\
3 \cdot 03 \\
4 \cdot 26 \\
5 \cdot 40\end{array}$ \\
\hline \multicolumn{5}{|c|}{ Babies bled at the age of 12 months } \\
\hline $\mathbf{S}$ & $\begin{array}{r}7 \\
11 \\
19\end{array}$ & $\begin{array}{c}0.005-0.02 \\
0.05 \\
0 \cdot 1-0.5\end{array}$ & $\begin{array}{l}0.02 \\
0.07 \\
0.33\end{array}$ & $\begin{array}{l}0.52 \\
0.93 \\
1.78\end{array}$ \\
\hline $\mathbf{T}$ & $\begin{array}{l}10 \\
15 \\
15 \\
11\end{array}$ & $\begin{array}{c}0.002-0.02 \\
005,0 \cdot 1 \\
0 \cdot 2 \\
0 \cdot 5,1 \cdot 0\end{array}$ & $\begin{array}{l}0.02 \\
0.11 \\
0.32 \\
0.87\end{array}$ & $\begin{array}{l}0.75 \\
1.88 \\
2.55 \\
2.94\end{array}$ \\
\hline $\mathbf{V}$ & $\begin{array}{l}16 \\
24 \\
17\end{array}$ & $\begin{array}{c}0.02,0.04 \\
0 \cdot 1,0.2 \\
0.5,1.0\end{array}$ & $\begin{array}{l}0.06 \\
0.23 \\
0.83\end{array}$ & $\begin{array}{l}0.99 \\
1 \cdot 39 \\
3 \cdot 31\end{array}$ \\
\hline $\mathbf{Y}$ & $\begin{array}{r}22 \\
25 \\
20 \\
8\end{array}$ & $\begin{array}{c}0.02-0 \cdot 1 \\
0 \cdot 2 \\
0 \cdot 5 \\
1 \cdot 0,2 \cdot 0\end{array}$ & $\begin{array}{l}0.09 \\
0.32 \\
0.71 \\
0.56\end{array}$ & $\begin{array}{l}1 \cdot 38 \\
1.81 \\
2 \cdot 05 \\
2 \cdot 59\end{array}$ \\
\hline \multicolumn{5}{|c|}{ Babies bled at the age of 15 months } \\
\hline $\mathbf{S}$ & $\begin{array}{r}9 \\
28\end{array}$ & $\begin{array}{l}0.5 \\
1 \cdot 0-5 \cdot 0\end{array}$ & $\begin{array}{l}0.71 \\
2.58\end{array}$ & $\begin{array}{l}4 \cdot 19 \\
10 \cdot 6\end{array}$ \\
\hline $\mathbf{T}$ & $\begin{array}{l}13 \\
15 \\
13\end{array}$ & $\begin{array}{c}0.1-0.5 \\
1 \cdot 0 \\
2 \cdot 0-10 \cdot 0\end{array}$ & $\begin{array}{l}0.52 \\
1.41 \\
5 \cdot 38\end{array}$ & $\begin{array}{c}9 \cdot 58 \\
8 \cdot 20 \\
13 \cdot 5\end{array}$ \\
\hline $\mathbf{v}$ & $\begin{array}{l}10 \\
18 \\
20\end{array}$ & $\begin{array}{c}0 \cdot 2,0 \cdot 5 \\
1 \cdot 0 \\
2 \cdot 0-10 \cdot 0\end{array}$ & $\begin{array}{l}0.60 \\
1.41 \\
4 \cdot 17\end{array}$ & $\begin{array}{c}5 \cdot 12 \\
8 \cdot 38 \\
11 \cdot 2\end{array}$ \\
\hline
\end{tabular}

employed by Dudley, May, and O'Flynn (1934), of each baby remained relatively constant, and some degree of correlation existed between the diphtheria titre eight weeks after the third injection and the tetanus titre three months after the reinforcing dose.

\section{Reaction Rates}

Reactions to the primary immunization were determined by a questionary which the parents were asked to fill in at the time of the first withdrawal of blood two months after the babies had received their third injections. Reactions after the reinforcing dose were similarly determined at the final attendance for withdrawal of blood about three months later. No parent of a baby receiving fluid triple prophylactic blamed a reaction to injection as a reason for discontinuing the primary course. A local reaction was taken as an area of swelling or erythema reported as lasting for over 24 hours. A general reaction was recorded if there had been a constitutional disturbance lasting over 24 hours.

Parents were asked-“"Has your baby ever had (a) a local swelling or $(b)$ a general upset within two days of receiving an immunization here ? If so, please state which injection was followed by this reaction. If a local swelling, state the severity and duration of the reaction and the nature of the treatment given. If a general upset, state the time of onset after the injection and duration of the reaction, whether the child was feverish, and what other symptoms the child developed."

Table VII shows the number of individual reactions after the first, second, third, and reinforcing injections divided into local, general, and dual reactions. By far the greatest number of local reactions followed the first injection of the adsorbed prophylactic, but this preparation did not cause any greater proportion of general reactions than the fluid
TABLE VII.-Summary of the Number of Local and General Reactions Following the Injection of Adsorbed and Fluid Diphtheria-Tetanus-Pertussis Prophylactic in Young Babies

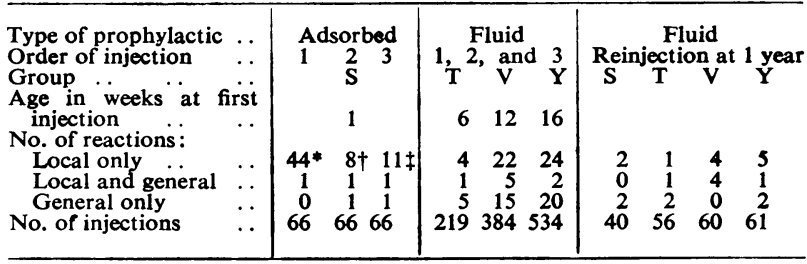

* Includes 9 sterile abscesses. † Includes 3 sterile abscesses. ‡Includes 5 sterile abscesses.

material. Thus, of 66 babies in group S, $53(80 \%)$ had local reactions -41 only once, 11 twice, and 1 three times in the primary course. This high reaction rate is in contrast to that of the other prophylactic groups, which involved 43 out of 379 babies $(10.8 \%)$, of whom 31 reacted once, 9 twice, and 3 thrice ; over 1,100 injections were given in the primary course. Similarly, the sterile abscess rate was 17 from 198 injections $(8.5 \%)$ of adsorbed material, while there were no abscesses following fluid prophylactic injections. The mildness of the local reactions in the fluid groups is shown by the fact that only 5 of the 58 reactions lasted more than three days, and no reaction lasted more than 28 days.

The general reaction rate was low in all groups. With the adsorbed prophylactic only 4 of the 66 babies $(6 \%)$ and with the fluid prophylactic 36 out of 379 babies $(9.4 \%)$ had a general reaction during the primary course. The slightly lower rate in group $S$ may be due to the earlier age at which the injections were given. Table VIII shows

TABLE VIII.--Incidence of General Reactions Analysed According to the Age of the Babies When Injected

\begin{tabular}{c|cccc}
\hline $\begin{array}{c}\text { No. of Broup: } \\
\text { Age when Injected } \\
\text { (Weeks) }\end{array}$ & $\begin{array}{c}\text { S } \\
66\end{array}$ & $\begin{array}{c}\mathrm{T} \\
73 \\
\text { Percentage with General Reactions }\end{array}$ & $\begin{array}{c}\mathbf{V} \\
178\end{array}$ \\
\hline 1 & 1.5 & & & \\
6 & 3.0 & 0.0 & 4.7 & \\
12 & 3.0 & 2.7 & 4.7 & 5.6 \\
16 & & 5.5 & 6.3 & 2.8 \\
18 & & & 6.3 & 3.9 \\
20 & & & & \\
\hline
\end{tabular}

that there was a tendency for fewer general reactions to follow injections of either type of prophylactic given at an early age. The percentage of such reactions was only once over 3 in six sets of figures for injections given at the age of 14 weeks or less, and only once less than 3 when the injections were given at 16 weeks or more. This agrees with the well-known fact that general reactions are minimal in the first few weeks of life; for, among 45 local reactions occurring after the firse injection of adsorbed prophylactic at 1 week of age, only one was reported to have been followed by a general reaction. General reactions were reported in 51 babies $(13.4 \%)$ in all groups; these suffered 63 general reactions in a total of just over 1,500 injections, including the reinforcing dose. The frequency "of various symptoms is analysed in Table IX. Fever was the most

TABLE IX.-Summary of the Number of General Reactions Analysed According to Symptoms

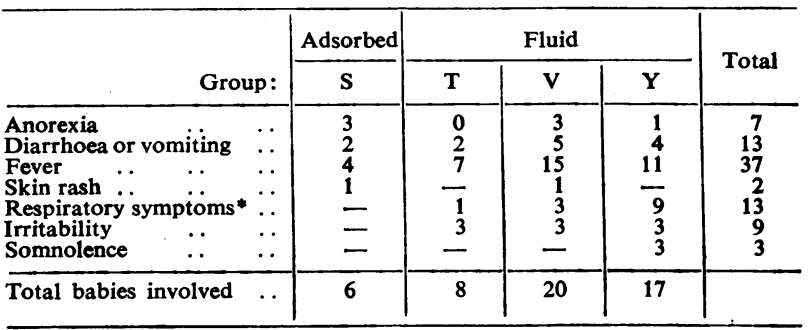

* Cough, coryza, bronchitis, wheezing. 
common symptom. One baby developed a paroxysmal cough following the second and third injections, thought by the parents to be whooping-cough, but this was of only 24 hours' duration on each occasion.

There was no marked difference in the proportion of the total number of reactions according to the order of the three injections of fluid prophylactic in the primary course. On each occasion 379 injections were made ; the total number of resulting reactions were 38,29 , and 31 respectively. The average ages at which the injections were given were $10.9,15.5$, and 20.3 weeks. The total number of reactions was least on all three occasions among the babies in group $T$ first injected with fluid prophylactic when 6 weeks old. The proportion of babies with any kind of reaction was 4.1, 5.5, and 5.5 after successive injections. Similar figures for group V starting at 12 weeks were $12.5,10.9$, and $9.4 \%$, and for $Y$ starting at 16 weeks $10.7,6.7$, and $8.4 \%$. Thus age at the time of injection is not the only factor influencing the appearance of reactions after any particular injection. Reactions to the third injection of fluid prophylactic were more frequent among those babies who had reacted before. Among the three groups together, reactions followed the third injection in $17(5.2 \%)$ of 326 babies who had not previously reacted, and in $14(26.4 \%)$ of 53 who had reacted before. This was specially marked in group $\mathrm{Y}$ : of 19 babies with reactions after the first injection, $9(47.4 \%)$ reacted to the second and the third injection also, while $6(3.6 \%)$ reacted out of 168 who had not reacted after either of the first two injections. General reactions were three times as frequent after injections causing local reactions than after those not followed by local reactions.

If local reactions are to be avoided when using a combined prophylactic containing pertussis vaccine given by the subcutaneous route, it is essential to use a fluid preparation.

\section{Summary}

Satisfactory diphtheria and tetanus antitoxin titres followed the use of a fluid combined diphtheria-tetanuspertussis prophylactic.

When these injections were given at intervals of four weeks, starting at the age of 12 or 16 weeks, only one baby among 330 had a diphtheria titre below that usually regarded as the Schick level, when tested eight weeks after the third injection. Over $93 \%$ had titres at least ten times this level; over $75 \%$ had titres above 0.2 unit. Of 240 babies tested when 12 months old, none was below the Schick level and $90 \%$ had titres at least ten times this level.

Results were less satisfactory in the group receiving the first injection of the fluid preparation at the age of 6 weeks.

The adsorbed triple prophylactic caused severe reactions, and although diphtheria titres were satisfactory when the babies were 6 months old they fell rapidly during the next six months.

The tetanus antitoxin titres of all babies were above 0.1 unit per $\mathrm{ml}$. on each occasion of bleeding. At the age of 6 months $95 \%$ of 460 tested had at least 1 unit per $\mathrm{ml}$.

There was a rough correlation between the diphtheria and tetanus responses.

We are indebted to the staff of the child welfare department of University College Hospital for their co-operation.

\section{REFERENCES}

Barr, M. (1954). Proc. roy. Soc. Med., 47, 352.

-
and Llewellyn-Jones, M. (1953). Brit. J. exp. Path., 34, 12.

Bousfield, G., and Holt, L. B. (1954). Med. Offr, 92, 289. Spec, Rep. Ser.

Dudley, S. F., May, P. M., and O'Flyn

Gleth. Bact., 34, 143. Glenny, A. T., and S. F. (1938). J. roy. Army med. Cps, 70, 308.
IMMUNIZATION AGAINST DIPHTHERIA AND WHOOPING-COUGH COMBINED v. SEPARATE INOCULATIONS

BY

VIOLET SPILLER, M.D., D.P.H. Assistant County Medical Officer, Barking Health Area, Essex C.C.

JOAN M. BARNES, B.SC. Wright-Fleming Institute, London, W.2

L. B. HOLT, D.Sc.

Wright-Fleming Institute, London, W.2

AND

\section{E. Cullington, M.B., D.C.H., D.P.H. Medical Officer of Health, Barking}

During recent years increasing attention has been directed to the use of combined diphtheria-whoopingcough prophylactics. The following are the main advantages: (a) Fewer injections are needed to ensure protection against both diphtheria and whooping-cough -a matter of great importance to all concerned. (b) The use of a combined prophylactic without alum in any form, and given very early in life, may minimize the small risk of post-inoculation paralytic poliomyelitis, particularly so when administered subcutaneously. (c) A high diphtheria immunization rate is maintained: mothers demand whooping-cough immunization, but may not bother to bring their infants back for separate diphtheria inoculations (Bousfield, 1951, 1952 ; Bousfield and Holt, 1953, 1954).

The combined method had been in use in Barking since 1947, and continued to be employed after the "appointed day." In early 1953 the Essex County Council decided to introduce a scheme for whoopingcough immunization throughout the county. This scheme involved three injections of suspended whoopingcough vaccine, which were to be followed later by two separate injections of A.P.T. as diphtheria prophylactic. The supply of combined prophylactics was to be discontinued, presumably because of the suggestion that the development of diphtheria antitoxin might be impaired by residual maternal antibody when the prophylactic is administered in the first few months of life (Barr, Glenny, and Randall, 1950).

In view of the keen interest of one of us (V.S.) in the use of diphtheria-pertussis prophylactic-W.D.P. (red) -aroused by the report of Bousfield (1952), an approach was made to the then county medical officer, who kindly agreed that the use of combined immunization might continue in the Barking area for purposes of research. The Wright-Fleming Institute was therefore approached for a supply of their combined prophylactic-W.D.P. (red)-for the purposes of the investigation, which was from thereon planned jointly.

The following is an account of a small field trial, the main purpose of which was to ascertain whether or not satisfactory diphtheria antitoxin responses were obtained in infants following a course of combined diphtheriapertussis prophylactic injections begun before the age of 6 months.

Strictly comparable figures-not previously available -were also provided whereby the relative efficiency of 